\title{
Tree Pruning in Electrical Network: Topic and Fundamentals in Machines and Robots
}

\section{Poda de árboles en la red eléctrica: tema y Fundamentos en máquinas y robots}

\section{Leandro Barragan Castellanos}

Robotic Laboratory "Raul Guenther" - Federal University of Santa Catarina -Florianopolis - Brazil leandro.b.castellanos@ posgrad.ufsc.br

\section{Roberto Simoni}

Center for Mobility Engineering - Federal University of Santa Catarina - Joinville - Brazil roberto.simoni@ufsc.br

\section{Daniel Martins}

Robotic Laboratory "Raul Guenther" - Federal University of Santa Catarina -Florianopolis -Brazil daniel.martins@ufsc.br

\section{Rodrigo de Souza Vieira}

Robotic Laboratory "Raul Guenther" -Federal University of Santa Catarina - Florianopolis - Brazil rodrigo.vieira@ufsc.br

\footnotetext{
Abstract

This paper presents a current literature and techno $\neg$ logical revision of tools and equipment for tree pruning or forest cutting in the electricity and telecommunications lines, showing a research methodology based on consultation of patents and databases of national projects, selecting the more representative.

In the end, it proposes a panorama of the market and identifies possible innovations and suggestions for news and better machines for the area.
} 
Keywords: Tree Pruning, Tree Trimming, Forestry, Walking Tractor, ANSI A300, ABNT NBR 162461

\section{Resumen}

Este artículo presenta una revisión actual de la literatura y la tecnología de herramientas y equipos para la poda de árboles o la tala de bosques en las líneas de electricidad y telecomunicaciones, mostrando una metodología de investigación basada en la consulta de patentes y bases de datos de proyectos nacionales, seleccionando a los más representativos.

Al final, propone un panorama del mercado e identifica posibles innovaciones y sugerencias de novedades y mejores máquinas para el área.

Palabras claves: Poda de árboles, silvicultura, tractor andante, ANSI A300, ABNT NBR 16246-1

\section{INTRODUCTION}

This paper presents the state of the art related to the pruning of trees or forest cutting in the electric network and telecommunications lines, relating concepts focused on the standardization, legislation, techniques, procedures and equipment that currently exist. The objective is to provide an explanatory material that is easy to understand for the general public on this environmental theme, creating awareness about the preservation of urban forests at the cities, and encouraging a healthy coexistence of tree species side by side with urban and rural electrification.

Environmental policies, and the development of social re $\neg$ sponsibility norms of energy distribution companies are vital to the current society. Awareness about the conservation of trees in urban areas and urban forests in parks and public squares, forces us to ensure an adequate coexistence of these species in relation to electrical and telecommunications networks. Nevertheless, in many cases, the existence of branches in the nets can have consequences as:

1)Interference in the power supply (the tree can remain as ground wire in the electric line). See [1] .

2)Causes fires in the electrical network due to short-circuit or lightning. See [2].

3)Be home to insects (bees and wasps), birds, bats and rodents that can interfere with the operation of the power grid. See [2].

This coexistence can only be guaranteed by the correct prun $\neg$ ing of the branches of the tree, made by qualified professionals using the right tools. A cut pattern should be followed in order to not damage the specimen, and allow it to continue its natural cycle of growth.

According to [3]"the pruning action is defined as the partial removal of branches from the plant, pruning modifies its structure and consequently its state of development. It is an agronomic / forestry technique that, depending on the arboreal specimens in which it is applied, has certain and specific purposes". 


\section{PROCEDURES, LAWS AND STANDARDS}

There are normative provisions and procedures that are found in manuals and internal norms of the companies, used on training courses for their employees, or contracted outsourced companies, that perform the service on Urban and rural areas. The international standard referenced is the standard ANSI A300 [4]. In Brazil, the "Special Forest Management Study Commission (ABNT / CEE-103)" [5] was created by ABNT1 in 2013, bringing together representatives of the country's electricity distribution to draw up the draft national technical standard ABNT NBR 16246- 1 [5].

On each capital and municipality of the Brazilian states, the Secretariats of the Environment and Natural Resources are in charge of supervising and reviewing the correct execution of the pruning. All companies that carry out pruning or plant suppression must be licensed to IBAMA2 and must renew this license every year, and comply with the reforestation established by law. At present, there is the International

Society of Forestry (ISA) and the SBAU3, which offer the pruning course worldwide at the same time they regulate cutting and cutting times for each region, in regards to each species.

\section{METHODOLOGY}

Two search activities were carried out: The Bibliographical Review for general aspects of the theme in scientific articles, and a Technological Review by patents and the Manufacturers Web Sites reading. Also, an extensive review was carried out at the level of technical manuals of Electrical Companies, tech $\neg$ nical catalogs, and projects using the R+D National Database of ANEEL.4 .

1) Google ${ }^{\circledR}$ Patents

2) INPI8

3) WIPO [16]

4) LENS $^{\circledR}[17]$

In the technological research of patents, the technical terms used were in [7]:

Pruning, Tree Trimming The Table I shows the related patent IPC's9:

\section{A. Bibliographical Review}

In [6] there are references to manufacturers and inventors of equipment and machines specialized in pruning of energy networks, at the same time they shown some representative patents. In [7] it is shown a vehicle-level application with a remote operated arm in Brazil with the project for COELBA5, and in Israel with the device "Tri-jib" [8], which is an arm coupled with air-basket vehicles. From the "Walking robots" approach, the information related to the prototype developed by the John Deere Company was studied.

\section{B. Manuals and Standards}

A more thorough review led to the revision of International Standards, National Standards and Business Standards in the world and Brazil. At the national level some electrification companies and mayors of the cities, have procedures to prune the trees, that can be listed as follow:

1) COPEL6[ [9] 
2) RGE7 [2] [10]

3) Prefeitura de Sao Paulo [3]

4) PEPCO [11]

5) Gobierno Federal de Ciudad de Mexico [12]

6) Asociacion Chilena de Higiene y Seguridad [13]

7) COELBA [7] [14]

\section{Technological Review}

The Robotics Laboratory of the Federal University of Santa Catarina developed a methodology for patents searching which has as objective to find the greater number of information of a product from a preliminary search, and then a specific search, in the end. This provides a technological mapping, and measures the innovation potential that can be had on the product. The methodology proposed by [15] was originally applied to motors of variable compression rate, and other projects in the laboratory.

For the technological review patent search engines nation-ally and globally were used, such as:

\begin{tabular}{|c|c|c|}
\hline \multicolumn{3}{|c|}{ IPC'S PRINCIPALS } \\
\hline Item & IPC & Description \\
\hline 1 & A01D & Harvesting Mowing \\
\hline 2 & AO1F & Threshing \\
\hline 3 & AO1G & Horticulture \\
\hline
\end{tabular}

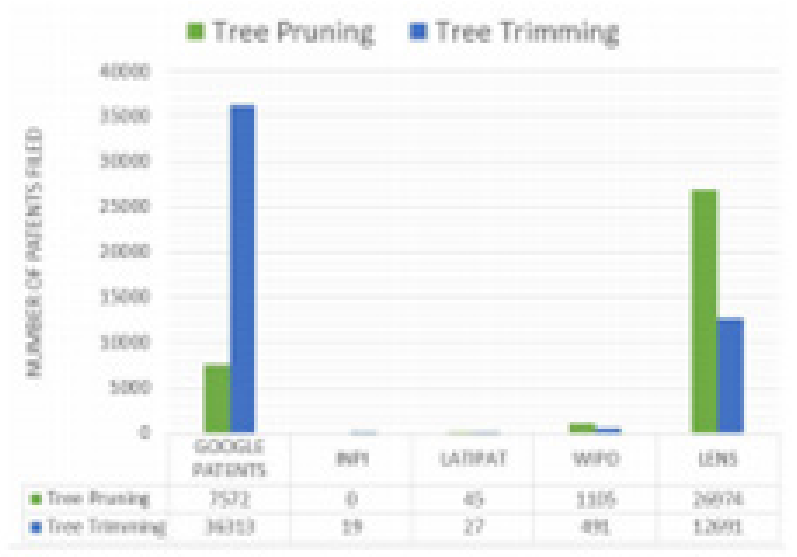

Fig. 1. Patent database search

1 A01D Harvesting Mowing

2 AO1F Threshing

3 AO1G Horticulture

In the preliminary search, we obtained the previous results in quantity of patents, as shown in Fig. 1. Obtaining better search results at the "Google ${ }^{\circledR}$ Patents" with the technical term "Tree Trimming" (36.313 patents) and the database patent "Lens" the best result was 
with the technical term "Tree Pruning" (26.974 patents).

In the specific search, the most related patents to pruning in electrical networks were filtered. The Fig. 2 shows the final number of patents per database. Finding in "Google ${ }^{\circledR}$ patents" (16 patents) and "Lens ${ }^{\circledR " ~(19 ~ p a t e n t s) ~ r e l a t i o n a l ~ w i t h ~ t r i m m i n g ~ a n d ~ p r u n i n g ~ t o o l s ~ a n d ~}$ machines.

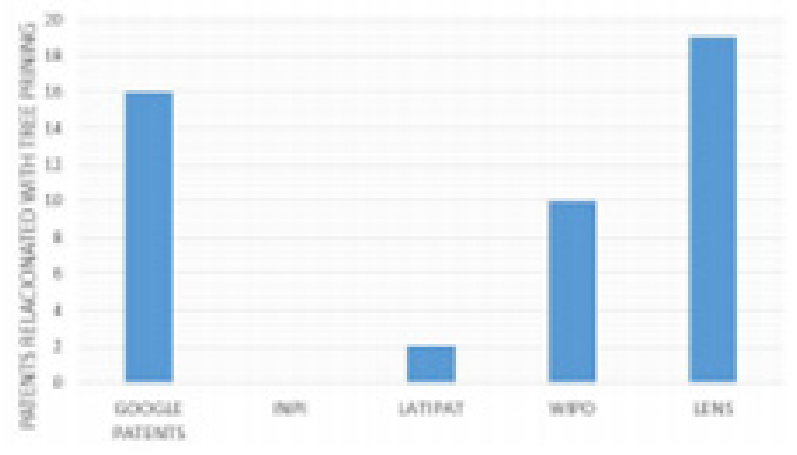

Fig. 2. Patents filtered

After the bibliographical and technological revision, a final list in the Table II is proposed in which three general types are proposed that classify this type of equipments related to the pruning, in each field there is an outstanding manufacturer which is the manufacturer that more patents deposited has for each type.

\begin{tabular}{|c|c|c|}
\hline Item & Types & Manufacturer \\
\hline 1 & Pruning Tools & Terratech $\AA[18]$. \\
\hline 2 & $\begin{array}{c}\text { Pruning } \\
\text { Vehicles }\end{array}$ & KW Truck Equipment ${ }^{\circledR}[19]$ \\
\hline 3 & Walking tractor & John Deere ${ }^{\circledR}[20]$. \\
\hline
\end{tabular}

TABLE II

\section{Research in National R+D Database}

The search into the national bank of $\mathrm{R}+\mathrm{D}$ projects of ANEELl ${ }^{\circ}$ [14], was made based on the worksheet with the last update of 2016, and the results of are shown by Table II. 


\begin{tabular}{|c|c|c|}
\hline Item & $\begin{array}{c}\text { Company, } \\
\text { statend } \\
\text { ANEEL Code }\end{array}$ & Description \\
\hline 1 & $\begin{array}{c}\text { CPFL (Sao } \\
\text { Paulo) PD- } \\
\text { O063013/2015 }\end{array}$ & $\begin{array}{c}\text { DE3013-Development of tool for } \\
\text { mechanized pruning at night to the } \\
\text { energized electric network coupled } \\
\text { to an urban light vehicle with } \\
\text { hybrid energy source. }\end{array}$ \\
\hline 2 & $\begin{array}{c}\text { Electropaulo (Sao Paulo) } \\
\text { PD-0390- } \\
\text { 1072/2013 }\end{array}$ & $\begin{array}{c}\text { Enviromentally correct set-up and } \\
\text { man-agement system to minimize } \\
\text { interruption of electrical energy. }\end{array}$ \\
\hline 3 & COELBA (Bahia) PD-0040062- & $\begin{array}{c}\text { Development of tooling equipment } \\
\text { and methodology for performing } \\
\text { pruning with energized network in } \\
\text { urban areas through mechanical } \\
\text { arms with remote control. }\end{array}$ \\
\hline 4 & CELESC & $\begin{array}{c}\text { Development of techniques and } \\
\text { procedures with the objetive } \\
\text { of optimizing the pruning and } \\
\text { mowing process in transmission } \\
\text { lines and MT distribution networks. }\end{array}$ \\
\hline & \multicolumn{2}{|c|}{ TABLE III } \\
\hline
\end{tabular}

\section{TOOLS AND EQUIPMENTS}

In the national market, there are different types of tools, from national and international manufacturers, that can be clustered as follows:

1) Pruning tools:

- Hand and grippers

- Hydraulic and motorized tools

2) Pruning vehicles:

- Special and adapted vehicles

- Walking Tractors

- Auxiliary equipment

The next sections describes each of the most important patents per area and the most representative equipment in pruning and forest cutting. The gripper saw tool shown in

Fig. No.5 of the manufacturer [17] is the most sophisticated tool to do this type of pruning that has two mechanisms, one that performs cutting from saws and another mechanism from the claws that can ensure the twig to be placed on the ground or in a shredder.

A. Pruning Tools

They are the most common, although they have the disad-vantage of being low ergonomic and generate discomfort for the person who performs the cut. Fig.3. Shows a typical handcut scissors that are widely used by arborists and gardeners. 


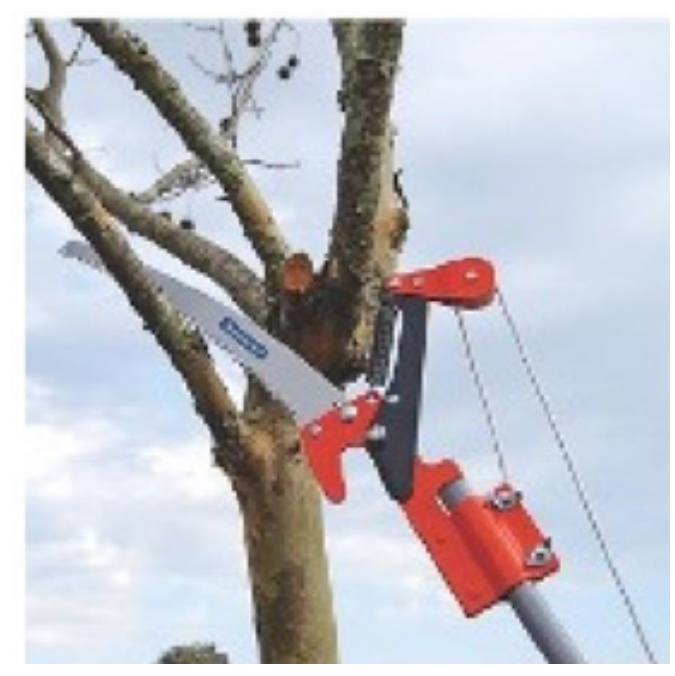

Fig. 3. Garden hacksaw by Tramontina ${ }^{\circledR}[21]$

The motorized tools are the main choice for the arborists, as show in Fig. 4. Here a pneumatic pruning tool developed for the CELPE 11 is used. Other pruning tools have cut mechanics of tree, show in Fig. 5 and Fig. 6.

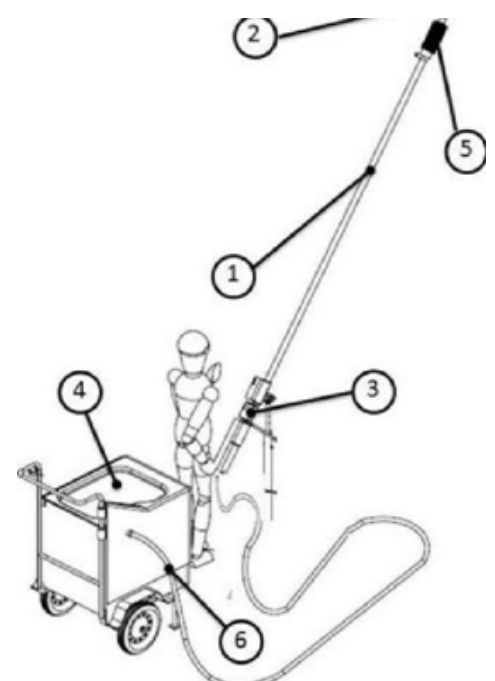

Fig. 4. Pneumatic saw of CELPE [22] 


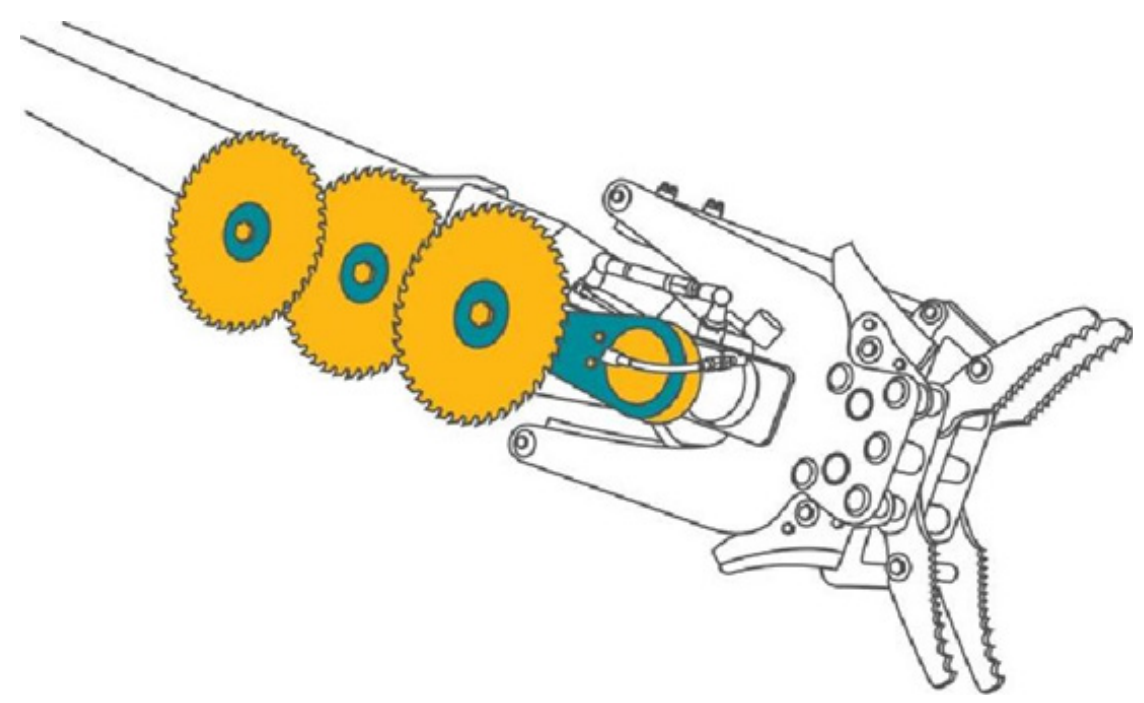

Fig. 5. Motorized equipment with saw disc development by Terratech ${ }^{\circledR}$ [18]

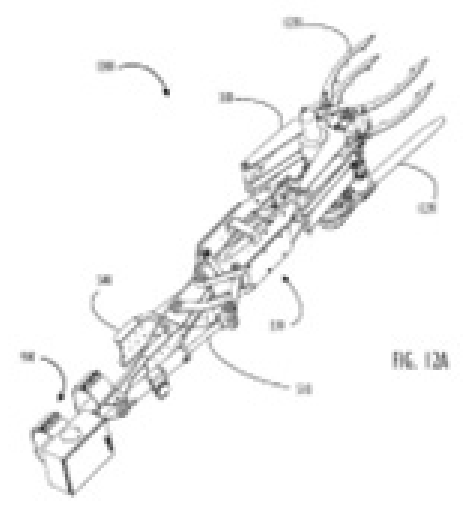

Fig. 6. Motorized equipment with chainsaw WO2012151394 patent [23]

\section{B. Pruning Vehicles}

Adapted vehicles allow performing the task of pruning, using hydraulic drives that allow to couple of tools to com $\neg$ plement the work in air baskets and agricultural tractors. One example is the "breaks tree vehicle" of Linha viva ${ }^{\varpi}$ Company [24]. See Fig. 7. 


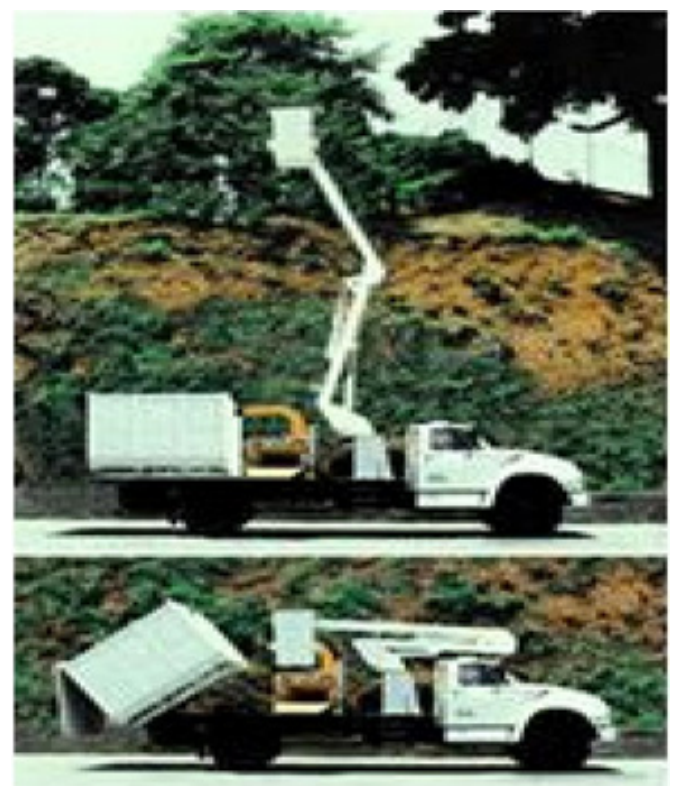

Fig. 7. "Break tree vehicle" [24]

There are more robust devices to carry out this type of work like the equipment of KW Truck Equipment ${ }^{\circledR}$ Company [19] from the United States, as shown in Fig. 8 and Fig 9.

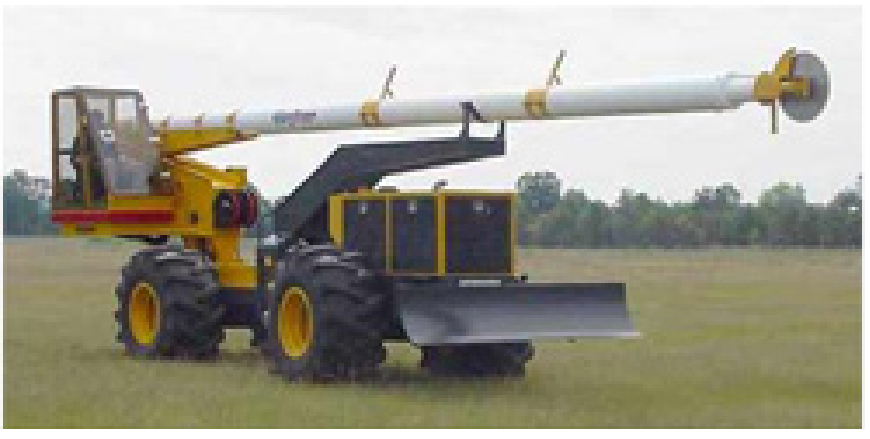

Fig. 8. Tractor with saw disc [25] 


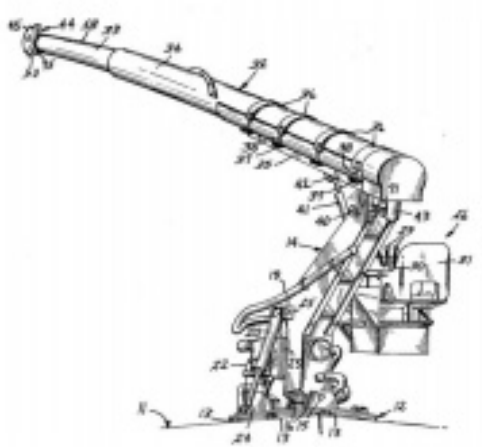

Fig. 9. Hydraulic saw disc US4111070 patent [26]

There are pruning equipments that work with the power take-off of the tractor and can do specific forestry pruning in agriculture, and forestry pruning. See Fig. 10 and Fig. 11.

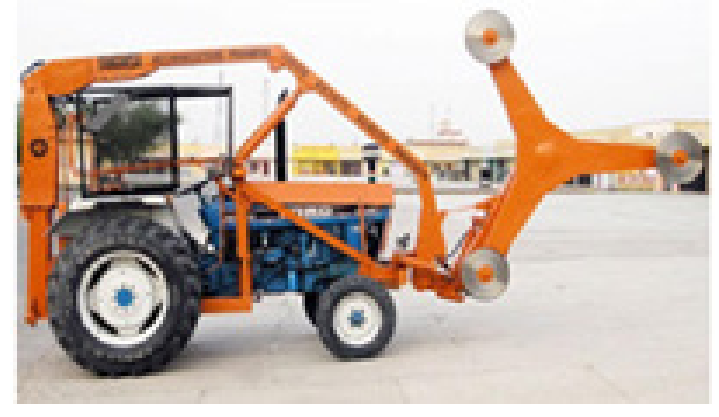

Fig. 10. Pruner tractor [27]

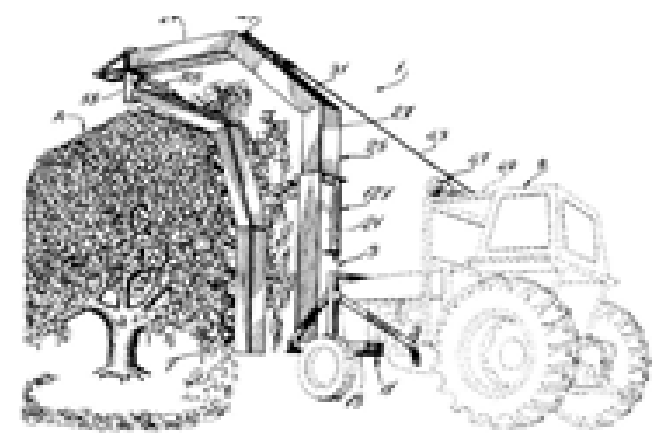

Fig. 11. Pruner tractor US3913304 patent [28]

The Fig. 12 [29] shows a patent for a complete invention of a truck that has cut pruning crushing. This record was published in 2016 by the inventor (Meng-Chyang PENG). 


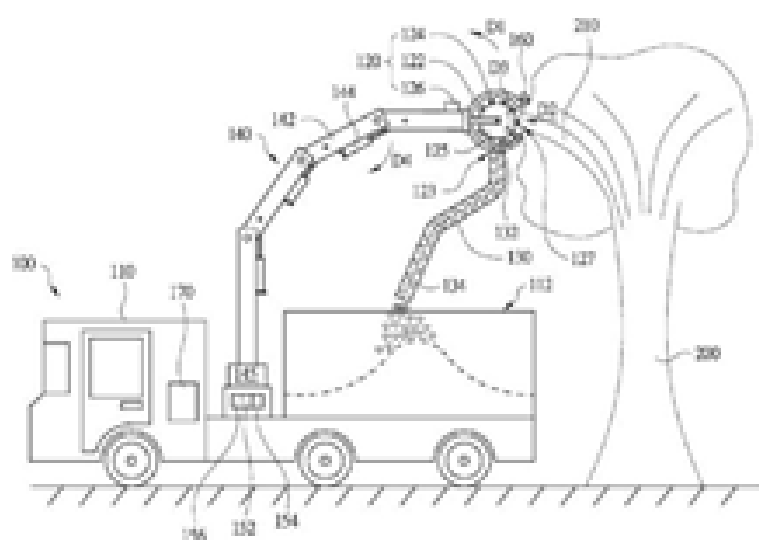

Fig. 12. "Tree trimming apparatus" US201600295576 Patent [29]

The Terratech ${ }^{\circledR}$ Company [18] markets this turntable equip $\neg$ ment, which has the facility to operate with remote control. It is a truck-mounted equipment and is marketed in the United States and Canada. See Fig. 13.

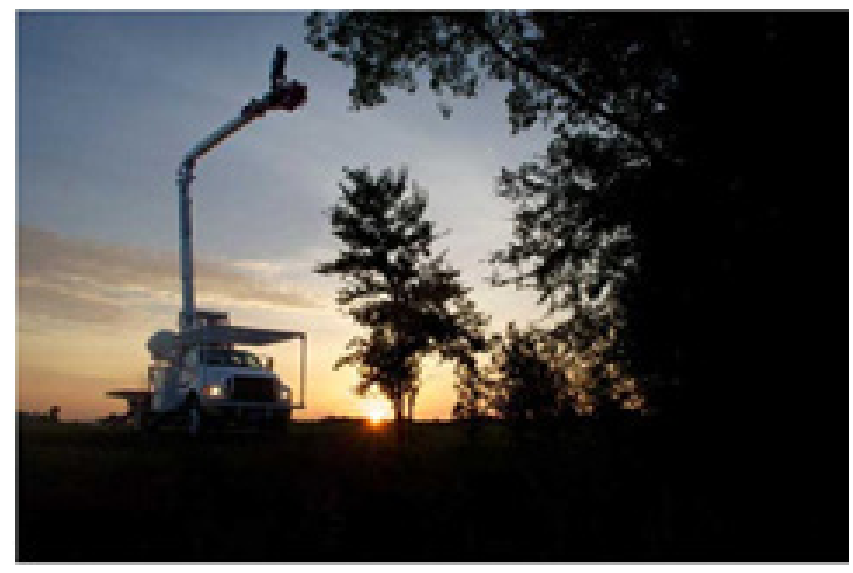

Fig. 13. Truck with saw tool [18]

There are other similar equipments, having a similar con-figuration as is the case of this patent (US 4667227), discloses equipment similar to the Terratech ${ }^{\circledR}$ one, as shown in Fig. 14. 


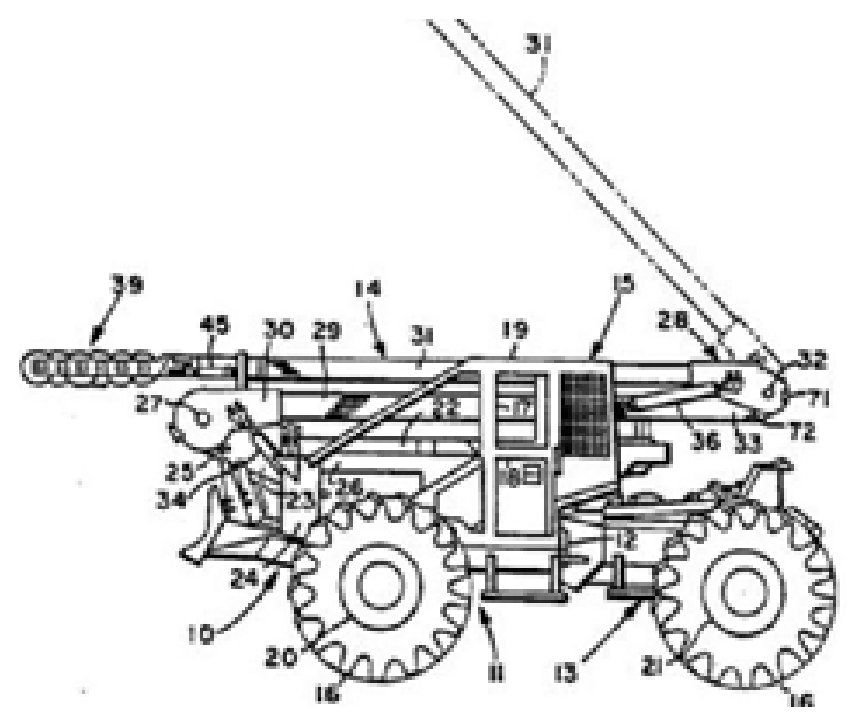

Fig. 14. Vehicle with saw tool US 4667227 patent [30]

\section{Walking Tractors}

There are vehicles that have special mechanisms to access difficult places that can prune rural forests and mountains. Is the case of the "Walking Tractor" development for John Deere ${ }^{\circledR}$ In partnership with the Plustech ${ }^{\circledR}$ Company from Finland, searching for the Plustech ${ }^{\circledR}$ Company [31] [32]. See Fig. 16 and 17.

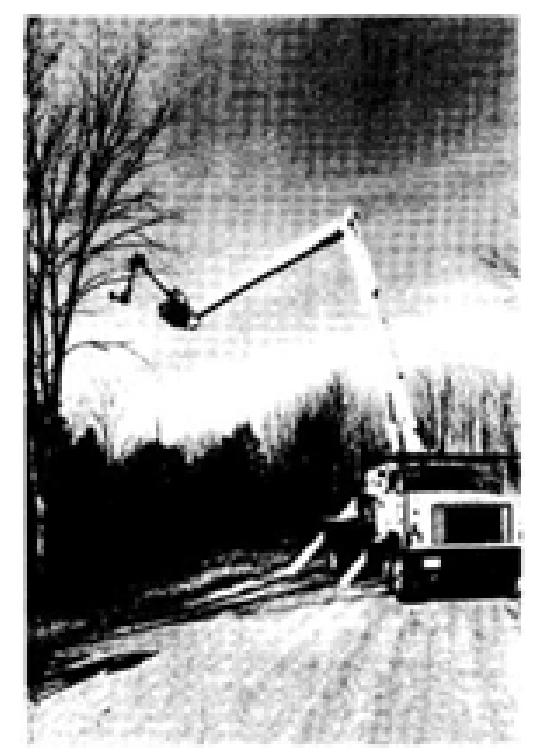

Fig. 15. "Tree jib" vehicle [8] 


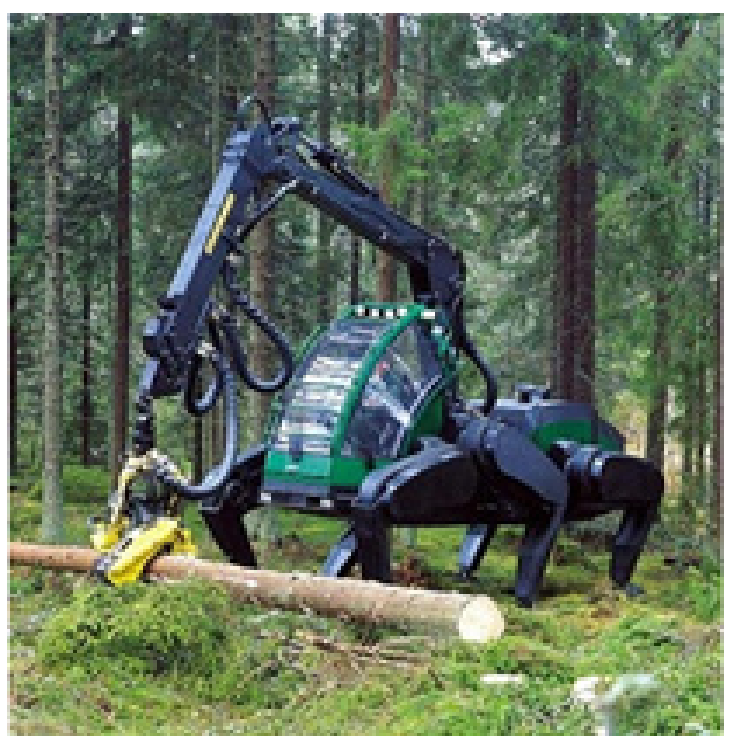

Fig. 16. "Walking Tractor" (John Deere® - Plustech®) [32]

There are adapting equipment such as the extension of crane boom or better known as "tree jib" that allows at its tip a motorized tool to prune the tree. See Fig. 15.

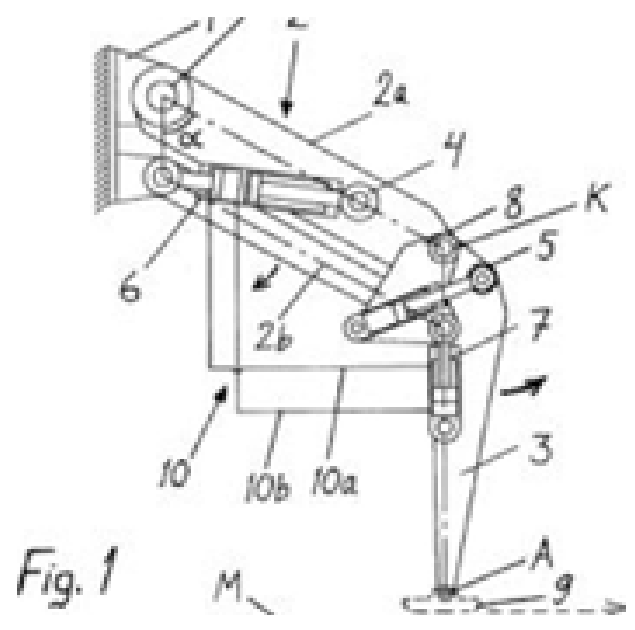




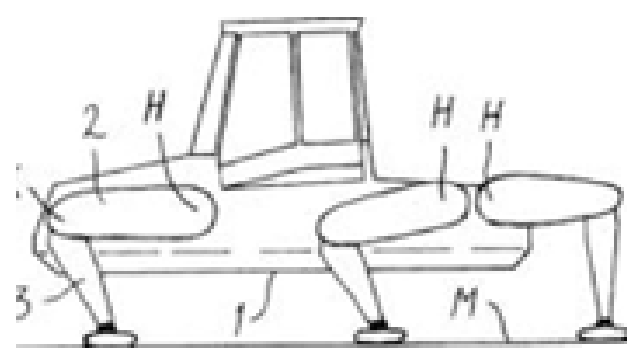

Fig. 17. Leg mechanics US6109378 patent [31]

The off-road systems are machines used in the part of urban pruning and can have access to difficult places like the walking tractors. At the information site on off-road system, we can see the vehicles from different manufacturers, and there are different patents that can be found with the following keywords:

Articulated vehicle tractor, unusual off-road tractor

The Berky Mahmaschinen ${ }^{\circledR}$ Company [33] is a worldwide manufacturer of this type of vehicles. See Fig 18.

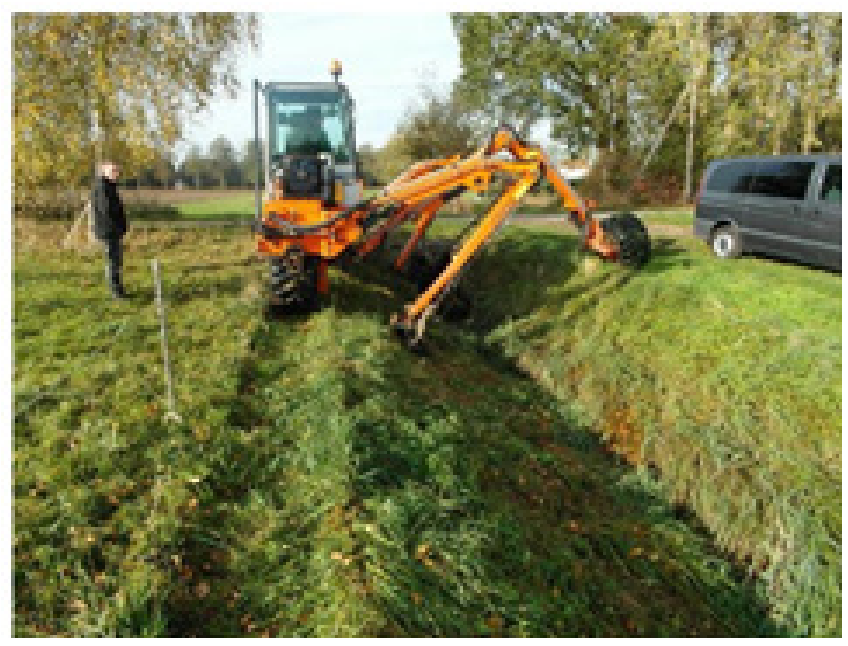

Fig. 18. Pruning tractor on roads [33]

\section{POTENCIAL OF INNOVATION}

In Brazil and Latin America, few tools and local vehicles allow this pruning to work efficiently, crane manufacturers, air baskets must take into account this market, which in other countries are developed by companies specific to the sector. The development of specialized pruning vehicles as well as multi functional pruning tools for different species of trees, which can be adapted to air baskets and cranes (motorized pruning and fly jibs). With suitable insulation and vision systems that help the arborist do their job and avoid ergonomic problems for arborists. A remote operated system may be an operating alternative for pruning equipment although there are remote control systems developed in the United States, Canada and Israel. 


\section{REFERENCES}

[1]E. Conteddo, "Contra apagdo, Ibama reavalia norma para poda de arvore - Folha Vitoria," Folha Vitoria, 2010. [Online]. Available: http://www.folhavitoria.com.br/geral/ noticia/2010/02/contra-apagao-ibama-reavalia-norma-para-poda-de-arvore.html. [Accessed: 17-Jun 2017$]$.

[2]Rio Grande Energia, "RGE - Gestao Ambiental," 2015. [Online]. Availᄀable: http://www. gestaoambientalrge.com.br/ [Accessed: 17-Jun-2017].

[3]R. A. Seitz, "A Poda de Arvores," Curso Treinamento sobre Pod. em Especies Arboreas Florestais e Arborizacao Urbana, pp. 83-103, 1996.

[4]ANSI, A-300 Tree and Shrub Pruning American National Standard. Washington, 2008.

[5]L. Octavio et al., "Florestas Urbanas - Manejo de arvores , arbustos e outras plantas lenhosas - Parte 1" 2012.

[6]L. C. Siebert et al., "Teleoperagdo de um sistema robotizado para poda de arvores na proximidade de redes energizadas 1," XII Simposio Bras. Automagdo Intel., no. 2007, pp. $1-6,2015$

[7]L. C. Siebert, L. F. R. B. Toledo, P. A. B. Block, D. B. BahIke, R. A. Roncolatto, and D. P. Cerqueira, "A survey of applied robotics for tree pruning near overhead power Ind. CARPI 2014, pp. 1-5, 2015.

[8]A. A. Goldenberg, R. G. Fenton, J. Wiercienski, P. Kuzan, C. Szymczyk, and B. Shaver, "A Remote Manipulator for Forestry Operation," IEEE Trans. Robot. Autom., vol. 11, no. 2, pp. 185-197, 1995.

[9]COPEL, Manual de Instructies Tecnicas - Manutengdo de redes de distribucao, vol. 160909. Curitiva, 2012.

[10]Rio Grande Energia, "Manual de arborizacao e poda." 2017.

[11]PEPCO, "Los arboles y el servicio electric ${ }^{\circ}$ confiable," 2009. [Onᄀline]. Available: http:// www.pepco.com/uploadedFiles/ [Accessed: 17ᄀJun-2017].

[12]Gobierno del distrito federal de la ciudad de Mexico, "Manual Tecnico de Podas," 2008. [Online]. Available: http ://www.arboricultura.org .mx/wp-content/uploads/2013/01/ manualᄀtecnico-de-poda-nadf-001-rnat-2006-2008.pdf. [Accessed: 17-Jun2017].

[13]A. C. de Seguridad, "Prevencion de Riesgos Electricos," Achs, vol. I, p. 54, 2013.

[14]A. N. de E. Eletrica, "Projetos de Chamada Estrategica - Programa de Pesquisa e Desenvolvimento Tecnologico do Setor de Energia Eletrica" 2016. [Online]. Available: http:// www.aneel.gov.br/programa $\neg$ de-p-d. [Accessed: 24-Jul-2017].

[15]T. Hoeltgebaum, "Metodologia de busca de patente aplicada a motores de taxa de compressao variavel," 2016, p. 41.[Internal presentation].

[16]PatBase Analytics, "IPC report: Search results for

IPC class: B62D57/00," 2017. [Online]. Available:

http ://www.patbase.com/stats/class.php ?ipc=B62D57/00. [Accessed: 
26-Jun-2017].

[17]Lens, "The Lens," 2017. [Online]. Available: https://www.lens.org/lens/. [Accessed: 22Jun-2017].

[18]I. Terratech, "TreeMaster Series," 2017. [Online]. Available: http://www.terratechmfg. com/treemaster-series. [Accessed: 16-Jun 2017 ].

[19]KW Truck Equipment, "Used Equipment, Chippers, Track Vehicles, Skytrim, Jarraff, and Kershaw at KW Truck Equipment, LLC," 2017. [Online]. Available: http://www. kwtruckequipment.com/skytrim.htm. [Accessed: 17-Jun-2017].

[20]John Deere, "John Deere Timeline Inventions." [Online]. Available: https://www.deere. com/enUS/corporate/ourcompany/aboutus/history/ [Accessed: 20-Jun-2017].

[21]Tramontina, "Serrote Podador com Cabo," 2017. [Online]. Available: http://www. tramontina. com.br/p/78380781 -302-s errote-podador-com $\neg$ cabo. [Accessed: 17-Jun-2017]. [22]A. C. Valdiero, J. A. Cervi, L. A. Rasia, and C. E. Pozzobon, "Projeto e analise ergomica de um equipamento pneumatico para a poda de arvores," 2015.

[23]S. Terrel, "WO 2012/151394A2 - Tree Trimming", 2012.

[24]Linhaviva, "Linha viva equipamentos Ltda.," 2017. [Online]. Availᄀable: http://www. linhaviva.com.br/CT-QG.htmTopo. [Accessed: 17-Junᄀ2017].

[25]K. Equipment, "Chip Boxes Loaders Line Trimmers Skidders and Chippers at KW Truck Equipment LLC." [Online]. Availᄀable: http://www.kwtruckequipment.com/page3.htm. [Accessed: 16-Jun 2017$]$.

[26]R. Boyum, George; Renner Robert; Lovelace, "US 4411070 Tree-Trimming Apparatus" , 1983.

[27]Indiamart, "Tree Pruner - View Specifications Details of Tree Pruners by National Innovation Foundation - India, Gandhinagar - $\quad$ ID: 4320663148." [Online]. Available:

https://www.indiamart.com/proddetail/tree-pruner-4320663148.html. [Accessed: 09-Aug2017].

[28]P. Jodoin, "US3913304A - Tree Trimmer," US3913304A, 1975.

[29]P. Meng-Chyang, "US 201600295576 - Tree Trimming Apparatus". 2016.

[30]D. Raymond, "US4627227A - Right-of-way tree line trimmer",A, 1986.

[31]M. Paakkunainen, "US6109378A - Leg Mechanism", 2000.

[32]Futuristic news, "John Deere Walking Tractor Prototype -Futuristic NEWS," Futuristic news, 2017. [Online]. Available: http://futuristicnews.com/john-deere-walking-tractorprototype/. [Accessed: 17-Jun-2017].

[33]Berky, "Berky Mahmaschinen - Typ 2200 Boschungsmaher," Catalog, 2016. [Online]. Available: http://www.berky.de/89-Typ2200.html. [Ac $\neg$ cessed: 26-Jun-2017]. 